\title{
PECULIARITIES OF THE FREE RADICAL PROCESSES IN RAT LIVER MITOCHONDRIA UNDER TOXIC HEPATITIS ON THE BACKGROUND OF ALIMENTARY PROTEIN DEFICIENCY
}

\author{
G. P. KOPYLCHUK, O. M. VOLOSHCHUK \\ Yuriy Fedkovych Chernivtsi National University \\ Institute of Biology, Chemistry and Natural Resources, Ukraine; \\ e-mail: kopilchuk@gmail.com
}

The rate of superoxide anion radical, hydroxyl radical and hydrogen peroxide generation, the level of oxidative modification of mitochondrial proteins in the liver of rats with toxic hepatitis was investigated on the background of alimentary protein deficiency. We did not find significant increases of the intensity of free radical processes in liver mitochondria of rats maintained on the protein-deficient ration. The most significant intensification of free radical processes in liver mitochondria is observed under the conditions of toxic hepatitis, induced on the background of alimentary protein deprivation. Under these conditions the aggravation of all studied forms of reactive oxygen species generation was observed in liver mitochondria. The generation rates were increased as follows: $\mathrm{O}_{2}$ - by 1.7 times, $\mathrm{H}_{2} \mathrm{O}_{2}$ - by 1.5 times, ${ }^{\circ} \mathrm{OH}$-practically double on the background of accumulation of oxidized mitochondria-derived proteins. The established changes in thiol groups' redox status of respiratory chain proteins insoluble in $0.05 \mathrm{M}$ sodium-phosphate buffer ( $\mathrm{pH}$ 11.5), and changes of their carbonyl derivatives content may be considered as one of the regulatory factors of mitochondrial energy-generating function.

Key words: alimentary protein deficiency, acetaminophen, induced liver injury, reactive oxygen species, oxidative protein modification, mitochondrial proteins.

A ctive oxygen metabolites, such as superoxide anion radical, hydrogen peroxide, and hydroxyl radical [1], are known to participate in intracellular signaling, regulation of cellular functions, non-specific immune response etc. [2, 3]. Nevertheless, due to their high oxidative potential, the reactive oxygen species (ROS) are capable of damaging cell structure and inducing a number of chain reactions leading to uncoupling of integrative functions in the organism [4].

The mitochondrial respiratory chain is the primary producer of ROS-generating electrons [5, 6]. Certain cellular mechanisms protect against overproduction of $\mathrm{O}_{2}^{--}$in mitochondria and products of its following transformations [7]. The disruptions in these mechanisms may be considered the starting point of mitochondrial degradation, marked by opening of mitochondrial permeability transition pores in the inner mitochondrial membrane, decrease in membrane potential with simultaneous cytochrome $c$ release, and $\mathrm{Ca}^{2+}$-dependent activation of hydrolytic enzymes [8-10]. The sensitive target of ROS is mtDNA and the mitochondrial proteins [11].

The problem of damage to functioning of energy biotransformation system under alimentary deprivation of microelements remains insufficiently studied as yet $[12,13]$.

The deficiency of mitochondrial respiratory chain substrates, primarily NADH, is crucial for disruptions to functioning of energy production systems. As we had demonstrated earlier [14], the protein-deficient animals with hepatitis display increased ratio of mitochondrial $\mathrm{NAD}^{+} / \mathrm{NADH}$, indicating lacking in NADH concentration. Nevertheless, the animals with acetaminophen-induced hepatitis fed standard ration do not develop NADH deficiency, despite damage to functional activity of mitochondrial respiratory chain enzyme complexes in liver.

On the other hand, the defining factor in disruptions of energy production may be the changes in activity of energy-producing systems resulting from 
damaging effects of ROS on structural organization of nucleus-encoded or mitochondrion-encoded enzymatic complexes of mitochondrial respiratory chain may be [15].

Therefore, it is important to study the limiting factors of mitochondrial energy-producing systems under toxic liver lesions in animals maintained on rations with varying protein content.

The aim of the present study was to investigate the rate of ROS generation and oxidative modifications of mitochondrial proteins in liver of rats with toxic hepatitis on the background of alimentary protein deficiency.

\section{Materials and Methods}

The experiments were conducted on white rats of 90-100 g body mass aged 2-2.5 months. The experimental work was conducted in accordance with rules set by the 'European convention for the protection of vertebrate animals used for experimental and other scientific purposes' (Strasbourg, 1986). The animals were separated into solitary plastic cages with sand bedding, with ad libitum access to water. The daily rations were regulated according to principles of pair feeding.

The animals were separated into the following experimental groups: I - animals receiving complete semi-synthetic ration (C); II - animals receiving low-protein ration (LPR); III - animals subjected to acetaminophen-induced liver lesions receiving complete ration (H); IV - animals subjected to acetaminophen-induced liver lesions that were previously fed semi-synthetic low-protein ration (LPR+H).

The animals of the groups I and III were fed standard fodder containing 14\% protein (casein), $10 \%$ fat, and $76 \%$ carbohydrates, balanced with all the essential nutrients. The animals of the groups II and IV were fed isoenergetic fodder containing 4.7\% protein, $10 \%$ fat, and $85.3 \%$ carbohydrates, calculated after recommendations of the American Institute of Nutrition [13, 14].

The animals were fed the corresponding diet for four weeks. Afterwards, the acetaminophen-induced liver lesion was modeled by per os introduction of $2 \%$ starch suspension of acetaminophen in dose of $1 \mathrm{~g} / \mathrm{kg}$ body mass of animals for 2 days over $24 \mathrm{hrs}$. with corresponding probe [16].

Cervical dislocation was performed under light ether desensitization on day 31 of the experiment.

Mitochondrial fraction was separated by differential centrifugation in the following buffer medium: $250 \mathrm{mM}$ sucrose, $1 \mathrm{mM}$ EDTA, $10 \mathrm{mM}$ Tris-HCl; $\mathrm{pH} 7.4$ at $0-3^{\circ} \mathrm{C}$.

The rate of superoxide anion radical generation in mitochondrial fraction was measured with nitro blue tetrazolium test (NBT) [17].

Hydrogen peroxide content was measured after [18]. The working reagent was prepared by mixing reagent $\mathrm{A}\left(25 \mathrm{mM}\left(\mathrm{NH}_{4}\right)_{2} \mathrm{Fe}\left(\mathrm{SO}_{4}\right)_{2} \times 6 \mathrm{H}_{2} \mathrm{O}\right.$ in $2.5 \mathrm{M}$ $\left.\mathrm{H}_{2} \mathrm{SO}_{4}\right)$ and reagent $\mathrm{B}(100 \mathrm{mM}$ sorbitol $+125 \mu \mathrm{M}$ xylenol orange) in 1:100 ratio. In test tubes with $50 \mathrm{mM}$ potassium-phosphate buffer ( $\mathrm{pH}$ 6.0) was placed an aliquot of sample up to a total volume of $400 \mu \mathrm{l}$. Control sample was $400 \mu \mathrm{M}$ of buffer solution. $2.0 \mathrm{ml}$ of working reagent was added to each sample, mixed and incubated for 15 to $20 \mathrm{~min}$. under room temperature, than optical density was measured against control at $\lambda=540 \mathrm{~nm}$. Hydrogen peroxide content was determined against calibration plot and calculated per $1 \mathrm{mg}$ of total protein.

The rate of hydroxyl radical generation was measured after [19]. Incubation medium was as follows: 20 mmol deoxyribose, $1 \mathrm{mmol} \mathrm{H}_{2} \mathrm{O}_{2}, 20 \mathrm{mmol}$ sodium-phosphate buffer ( $\mathrm{pH}$ 7.4), a sample was added containing $200 \mu \mathrm{g}$ of protein. The solution was incubated for $30 \mathrm{~min}$. at $37^{\circ} \mathrm{C}$, than mixed with $0.5 \mathrm{ml}$ of $1 \%$ solution of thiobarbituric acid in $50 \mathrm{mM} \mathrm{NaOH}$ and $0.5 \mathrm{ml}$ of $2.8 \%$ solution of trichloroacetic acid. The resulting mixture was incubated for $20 \mathrm{~min}$. in boiling water bath, cooled, and extinction was measured at $\lambda=532 \mathrm{~nm}$. Rate of ${ }^{\circ} \mathrm{OH}$-generation was expressed as nmol$\cdot \mathrm{min}^{-1} \cdot \mathrm{mg}^{-1}$ of protein.

Mitochondrial proteins were extracted by method [20] that is based on principle of insolubility of products of mitochondrial translation in $0.05 \mathrm{M}$ sodium-phosphate buffer with $\mathrm{pH}$ 11.5. Mitochondria suspension was stored at $-20^{\circ} \mathrm{C}$ overnight. After thawing the suspension was centrifuged at $20000 \mathrm{~g}$ for $20 \mathrm{~min}$. The sediment was resuspended in $10 \mathrm{ml}$ of $0.05 \mathrm{M}$ sodium-phosphate buffer ( $\mathrm{pH}$ 11.5) and centrifuged at $20000 \mathrm{~g}$ for $20 \mathrm{~min}$. The procedure was repeated [15].

Protein carbonylation was assayed via amount of 2,4-dinitrophenylhydrazone derivatives, that are produced in reactions of oxidized amino acid residues with 2,4-dinitrophenylhydrazine, and expressed as nmol of carbonyl protein derivatives per mg of protein.

Protein SH-group content was determined with method based on reaction of Ellman's reagent (5,5'-dithiobis-(2-nitrobenzoic acid) (DTNB)) with $\mathrm{SH}$-groups. The products are disulfide and thioni- 
trophenyl anion (TNPA). The amount of TNPA is directly proportional to the amount of SH-groups of proteins that reacted with DTNB. The content of free SH-groups was calculated basing on molar extinction of $11400 \mathrm{M}^{-1} \cdot \mathrm{cm}^{-1}$ and expressed as nmol/ mg of protein.

The data statistics was processed with MS Excel software, and represented as mean \pm deviation. The statistical significance was determined with standard Student's $t$-test.

\section{Results and Discussion}

Liver mitochondria of rats with alimentary protein deprivation demonstrated no significant increase in production of superoxide anion radical (Fig. 1), hydrogen peroxide (Fig. 2) and hydroxyl radical (Fig. 3).

There were no statistically significant differences between carbonyl derivatives and free SH-groups content in liver mitochondria of this experimental group and the corresponding values of the control. We surmise that imbalance in functional activity of components of mitochondrial respiratory chain demonstrated by us [13] under alimentary protein deficiency results from interruptions in synthesis of particular subunits of the respiratory complexes, and not from a higher rate of their degradation.

We observed increased rates of generation of superoxide anion radical (1.3 times control values, Fig. 1) and hydroxyl radical (1.5 times control values, Fig. 3) in animals subjected to acetaminopheninduced liver lesions. Small quantities of ROS are normally produced in mitochondria as a result of

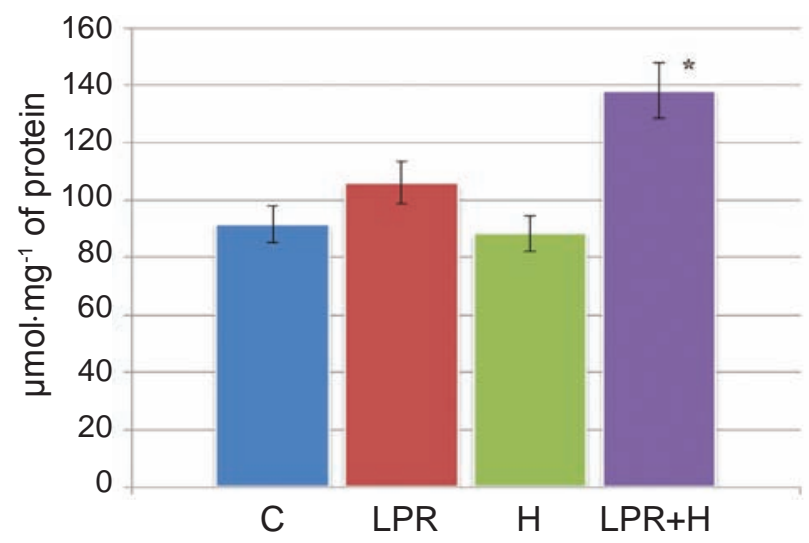

Fig. 2. Hydrogen peroxide $\left(\mathrm{H}_{2} \mathrm{O}_{2}\right)$ content in liver mitochondria under toxic hepatitis and alimentary protein deficiency

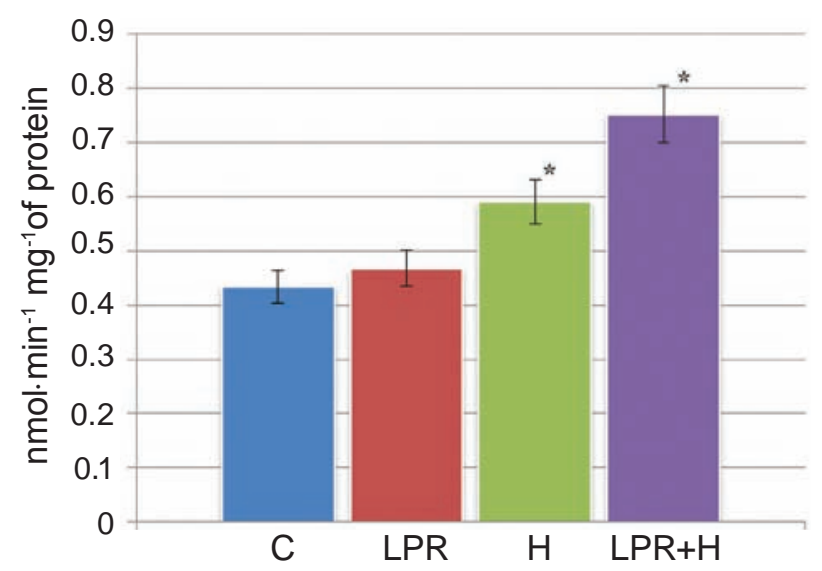

Fig. 1. Rate of superoxide anion radical $\left(\mathrm{O}_{2}{ }^{-}\right)$generation in liver mitochondria under toxic hepatitis and alimentary protein deficiency. Here and in Fig. 2-5: * difference from control significant with $P<0.05, n=9 ; C$ - animals receiving complete semi-synthetic ration; $L P R$ - animals receiving lowprotein ration; $H$ - animals subjected to acetaminophen-induced liver lesions receiving complete ration; $L P R+H$ - animals subjected to acetaminophen-induced liver lesions that were previously fed semi-synthetic low-protein ration

electron leakage from the respiratory chain. The primary points of ROS generation in mitochondria are complexes I and III of the respiratory chain $[6,7]$. Superoxide radicals from complex I dissipate into matrix and are quickly processed by mitochondrial superoxide dismutase into $\mathrm{H}_{2} \mathrm{O}_{2}$. The unstable semiquinone ( $Q^{*}$ ) radical is the source of $\mathrm{O}_{2}{ }^{--}$in complex III. It must be noted that the superoxide

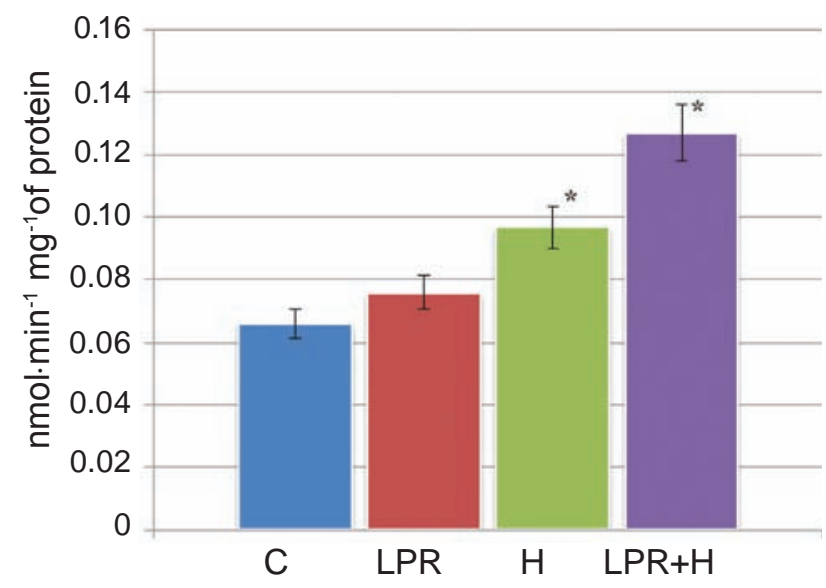

Fig. 3. Rate of hydroxyl radical ( $(\mathrm{OH})$ generation in liver mitochondria under toxic hepatitis and alimentary protein deficiency 


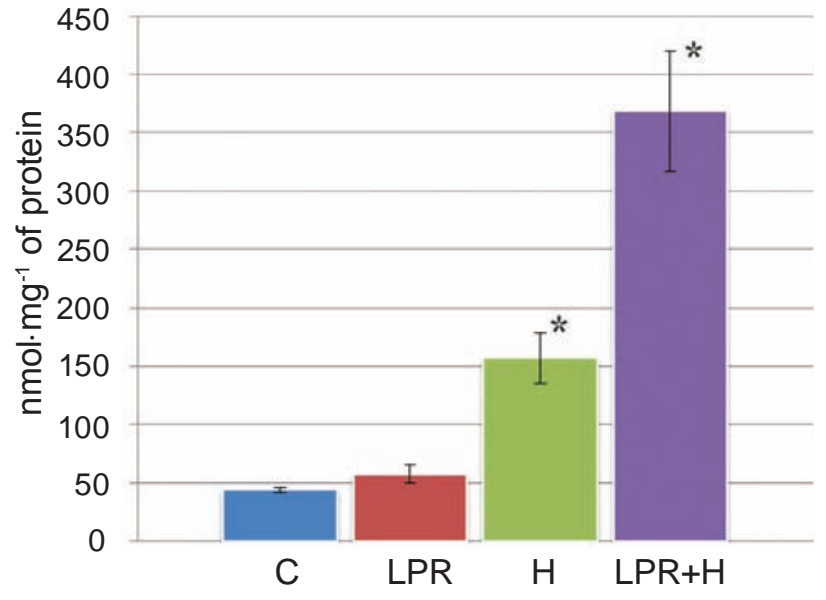

Fig. 4. Protein carbonyl derivatives content in liver mitochondria under toxic hepatitis and alimentary protein deficiency

radicals produced by complex I are vectored only in the direction of matrix, while the superoxide radicals from complex III are released both into matrix and into intermembrane space (and hence into cytosol). Other sources of ROS in mitochondria include outer membrane enzymes (cytochrome- $b_{5}$ reductase, monoamine oxidase $\mathrm{A}$ and $\mathrm{B}$, dihydroorotate dehydrogenase, glycerol-3-phosphate dehydrogenase), inner membrane enzymes (succinate dehydrogenase), and matrix enzymes (aconitase, $\alpha$-ketoglutarate dehydrogenase) [21]. The ROS that are generated by complexes I and III cause their oxidative inactivation. Complex I is the most sensitive to free-radical damage, while complexes II and III are much less sensitive. Since most oxidative metabolic pathways converge on mitochondria, and they bear numerous redox transporters and centers of ROS production, the biomolecules of mitochondria are in the most vulnerable position under conditions of oxidative stress [22].

We have demonstrated that ROS production in liver mitochondria of rats with toxic liver lesions is associated with intensification of oxidative damaging to mitochondrial proteins. Content of carbonyl derivatives of proteins insoluble in $0.05 \mathrm{M}$ sodiumphosphate buffer ( $\mathrm{pH}$ 11.5) in liver of the animals from this experimental group was 3.4 times higher than the corresponding value in control (Fig. 4), while free SH-group content was 1.4 times lower (Fig. 5). The level of oxidative damage to a protein molecule depends on its amino acid composition, structure, and exposure of amino acid residues to radicals [23]. The primary targets of ROS are

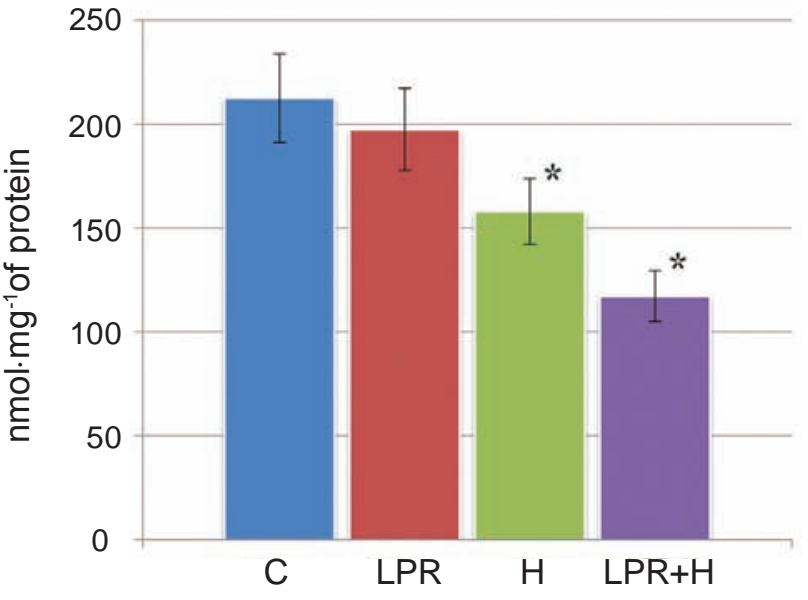

Fig. 5. Free SH-groups content in proteins of liver mitochondria under toxic hepatitis and alimentary protein deficiency

cysteine, histidine, tyrosine, phenylalanine, tryptophan, and methionine.

The intensified destruction of liver mitochondria proteins in animals with acetaminophen-induced hepatitis disrupts their functional activity. In accordance with observations from our previous experiments, the acetaminophen-induced hepatitis is associated with decreased enzymatic activity of the components of mitochondrial electron-transport chain $[14,16]$. Therefore, the changes in oxidation of thiol groups in proteins of the respiratory chain insoluble in $0.05 \mathrm{M}$ sodium-phosphate buffer ( $\mathrm{pH}$ 11.5), and changes in content of their carbonyl derivatives may be perceived as one of the regulative factors of mitochondrial energy production.

Nevertheless, the most pronounced intensification of free-radical processes in liver mitochondria was observed under toxic hepatitis induced on the background of alimentary protein deprivation. Under these conditions we detected increased generation of all the investigated ROS: 1.7 times the control values

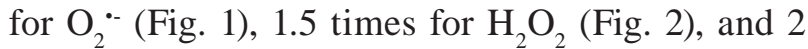
times for ${ }^{\circ} \mathrm{OH}$ (Fig. 3). The nature of oxidative damage may vary depending on the chemical character of the particular ROS. ${ }^{\circ} \mathrm{OH}$ chiefly causes protein aggregation, and protein fragmentation if acting concurrently with $\mathrm{O}_{2}{ }^{--}$. The aggregates are produced due to formation of intermolecular covalent bonds through tyrosine residues. The protein fragmentation results from cleavage of peptide bonds, and produces peptides with low molecular mass. Combined action of ${ }^{\circ} \mathrm{OH}$ and $\mathrm{O}_{2}{ }^{-}$- causes changes to primary, secondary and tertiary structure of the affected proteins [24]. 
$\mathrm{H}_{2} \mathrm{O}_{2}$ exhibits comparatively smaller modifying activity. Protein SH groups are the most sensitive to $\mathrm{H}_{2} \mathrm{O}_{2}$-induced oxidation. However, the damaging effect of $\mathrm{H}_{2} \mathrm{O}_{2}$ on biological objects is amplified by its membrane-permeating qualities [25].

It must be noted that the most pronounced accumulation of oxidatively modified mitochondriaencoded proteins was observed under toxic hepatitis on the background of alimentary protein deficiency. The content of carbonyl derivatives of mitochondrial proteins was 6.8 times higher than the corresponding control value, and 2.3 times higher than the corresponding value for experimental animals fed standard fodder (Fig. 4). Thiol groups' content in the investigated proteins is nearly half that of control group (Fig. 5). Sulfhydryl groups (-SH) of cysteine are known to oxidize into $-\mathrm{SOH},-\mathrm{SO}_{2} \mathrm{H}$, $-\mathrm{SO}_{3} \mathrm{H}$, and disulfide derivatives [26]. Formation of intramolecular and intermolecular disulfide bonds leads to changes in protein structure or causes their dimerization, and, as a result, may affect the efficiency of respiratory chain. Changes in content of modified proteins under these experimental conditions may be viewed as a signal for rearrangement of mitochondrial energy generation.

Thus, the under toxic liver lesions on the background of alimentary protein deficiency we observed the most pronounced intensification of free radicalinduced processes in liver mitochondria, associated with increased production of superoxide anion radical, hydroxyl radical, and hydrogen peroxide, as well as oxidative modifications of mitochondrial proteins.

These results lead to the conclusion that alimentary protein deficiency under toxic liver lesion conditions is a critical factor leading to increased oxidative damage to mitochondrial proteins.

The results may be the base for understanding of mechanisms of cellular metabolic response to alimentary protein deficiency, and biochemical grounds for developments in correction of consequences of imbalance in energy exchange under toxic hepatitis on the background of dietary protein deficiency.

The work was done within framework of the "Biochemical aspects of responsive integration of metabolism of the essential micronutrients" program, State Register No 0115U003231.

\section{ОСОБЛИВОСТІ \\ ВІЛЬНОРАДИКАЛЬНИХ ПРОЦЕСІВ У МІТОХОНДРІЯХ ПЕЧІНКИ ЩУРІВ ЗА ТОКСИЧНОГО ГЕПАТИТУ НА ТЛІ АЛІМЕНТАРНОЇ ПРОТЕЇНОВОЇ НЕДОСТАТНОСТІ}

\section{Г. П. Копильчук, О. М. Волощук}

\author{
Чернівецький національний університет \\ імені Юрія Федьковича, Інститут біології, \\ хімії та біоресурсів, Україна; \\ e-mail: kopilchuk@gmail.com
}

Досліджували інтенсивність генерації супероксидного аніон-радикала, гідроксильного радикала, пероксиду водню та рівень окислювальної модифікації мітохондріальних протеїнів у печінці щурів із токсичним гепатитом на тлі аліментарної протеїнової недостатносі. Встановлено, що в мітохондріях печінки тварин, яких утримували на раціоні 3 нестачею протеїну, вірогідного підвищення інтенсивності вільнорадикальних процесів не спостерігалося. Найвираженіша інтенсифікація вільнорадикальних процесів у мітохондріях печінки відбувалася за умов токсичного гепатиту. Показано посилення генерації всіх досліджуваних активних форм кисню: $\mathrm{O}_{2}^{--}$- 1,7 , a $\mathrm{H}_{2} \mathrm{O}_{2}-$ в 1,5 раза, ${ }^{\circ} \mathrm{OH}$ - практично в 2 рази на тлі акумуляції окисномодифікованих протеїнів, синтез яких детермінується мітохондріальним геномом. Встановлені зміни окисно-відновного стану тіолових груп протеїнів дихального ланцюга, нерозчинних в 0,05 M Naфосфатному буфері (pH 11,5), та зміни вмісту їхніх карбонільних похідних можна розглядати як один із факторів регуляції енергетичних функцій мітохондрій.

К л ю чо в $\quad$ с лов а: аліментарна протеїнова недостатність, ацетамінофен, індуковане пошкодження печінки, активні форми кисню, окислювальна модифікація протеїнів, протеїни мітохондріального кодування. 


\section{ОСОБЕННОСТИ \\ СВОБОДНОРАДИКАЛЬНЫХ \\ ПРОЦЕССОВ В МИТОХОНДРИЯХ \\ ПЕЧЕНИ КРЫС ПРИ ТОКСИЧЕСКОМ \\ ГЕПАТИТЕ, ИНДУЦИРОВАННОМ \\ НА ФОНЕ АЛИМЕНТАРНОЙ \\ НЕДОСТАТОЧНОСТИ ПРОТЕИНА}

\section{Г. П. Копыльчук, О. Н. Волощук}

\author{
Черновицкий национальный университет \\ имени Юрия Федьковича, Институт \\ биологии, химии и биоресурсов, Украина; \\ e-mail: kopilchuk@gmail.com
}

Исследованы интенсивность генерации супероксидного анион-радикала, гидроксильного радикала, пероксида водорода и уровень окислительной модификации протеинов митохондриального кодирования в печени крыс с токсическим гепатитом, индуцированным на фоне алиментарного дефицита протеина. Установлено, что в митохондриях печени животных, содержащихся на низкопротеиновом рационе, достоверного повышения интенсивности свободнорадикальных процессов не наблюдалось. Наиболее выраженная интенсификация свободнорадикальных процессов в митохондриях печени происходит при токсическом гепатите. Показано усиление генерации всех исследуемых активных форм кислорода: $\mathrm{O}_{2}{ }^{-}-$в 1,7 раза, $\mathrm{H}_{2} \mathrm{O}_{2}-$ в 1,5 раза, 'ОН - практически в 2 раза на фоне аккумуляции окисленных протеинов, синтез которых детерминируется митохондриальным геномом. Установленные изменения окислительно-восстановленного состояния тиоловых групп протеинов дыхательной цепи, нерастворимых в $0,05 \mathrm{M} \mathrm{Na-фосфатном} \mathrm{буфере}(\mathrm{pH} 11,5)$ и изменение содержания их карбонильных производных можно рассматривать как один из факторов регуляции энергетических функций митохондрий.

К л ю че в ы е слов а: алиментарная протеиновая недостаточность, ацетаминофен, индуцированное повреждение печени, активные формы кислорода, окислительная модификация протеинов, протеины митохондриального кодирования.

\section{References}

1. Bak MJ, Jun M, Jeong WS. Antioxidant and hepatoprotective effects of the red ginseng essential oil in $\mathrm{H}(2) \mathrm{O}(2)$-treated hepG2 cells and
CCl(4)-treated mice. Int J Mol Sci. 2012; 13(2): 2314-2330.

2. Conde de la Rosa L, Schoemaker MH, Vrenken TE, Buist-Homan M, Havinga R, Jansen PL, Moshage H. Superoxide anions and hydrogen peroxide induce hepatocyte death by different mechanisms: involvement of JNK and ERK MAP kinases. J Hepatol. 2006; 44(5): 918929.

3. Cadenas E. Mitochondrial free radical production and cell signaling. Mol Aspects Med. 2004; 25(12): 17-26.

4. Whaley-Connell A, McCullough PA, Sowers JR. The role of oxidative stress in the metabolic syndrome. Rev Cardiovasc Med. 2011; 12(1): 2129.

5. Liu Y, Fiskum G, Schubert D. Generation of reactive oxygen species by the mitochondrial electron transport chain. J Neurochem. 2002; 80(5): 780-787.

6. Tatarková Z, Kuka S, Račay P, Lehotský J, Dobrota D, Mištuna D, Kaplán P. Effects of aging on activities of mitochondrial electron transport chain complexes and oxidative damage in rat heart. Physiol Res. 2011; 60(2): 281-289.

7. Lenaz G. The mitochondrial production of reactive oxygen species: mechanisms and implications in human pathology. IUBMB Life. 2001; 52(3-5): 159-164.

8. Akopova OV, Kolchinskaya LI, Nosar VI, Bouryi VA, Mankovska IN, Sagach VF. The effect of ATP-dependent $\mathrm{K}(+)$-channel opener on transmembrane potassium exchange and reactive oxygen species production upon the opening of mitochondrial pore. Ukr Biochem J. 2014; 86(2): 26-40. (In Russian).

9. Ly JD, Grubb DR, Lawen A. The mitochondrial membrane potential (deltapsi(m)) in apoptosis; an update. Apoptosis. 2003; 8(2): 115-128.

10. Sun C, Guo XX, Zhu D, Xiao C, Bai X, Li Y, Zhan Z, Li XL, Song ZG, Jin YH. Apoptosis is induced in cancer cells via the mitochondrial pathway by the novel xylocydine-derived compound JRS-15. Int J Mol Sci. 2013; 14(1): 850-870.

11. Lagouge M, Larsson NG. The role of mitochondrial DNA mutations and free radicals in disease and ageing. J Intern Med. 2013; 273(6): 529-543.

12. Theys N, Bouckenooghe T, Ahn MT, Remacle C, Reusens B. Maternal low-protein diet alters 
pancreatic islet mitochondrial function in a sexspecific manner in the adult rat. Am J Physiol Regul Integr Comp Physiol. 2009; 297(5): R1516-R1525.

13. Voloshchuk ON, Kopylchuk GP, Kadayskaia TG. State of the energy-supply system of the liver mitochondria under the conditions of alimentary deficiency of protein. Vopr Pitan. 2014; 83(3): 12-16. (In Russian).

14. Kopylchuk GP, Voloshchuk OM. NADH:ubiquinone reductase and succinate dehydrogenase activity in the liver of rats with acetaminopheninduced toxic hepatitis on the background of alimentary protein deficiency. Ukr Biochem $J$. 2015; 87(1): 121-126. (In Ukrainian).

15. Marchenko MM, KopylchukHP, VoloshchukOM. Effect of low doses of ionizing radiaton on the fractional content of mitochondrial proteins and mtDNA in Guerin's carcinoma. Ukr Biokhim Zhurn. 2008; 80(4): 114-119. (In Ukrainian).

16. Voloshchuk ON, Kopylchuk GP. The peculiarities of the structural and functional state of the cytochrome component of the liver mitochondrial respiratory chain under conditions of acetaminophen-induced hepatitis on the background of alimentary protein deprivation. Biophysics. 2015; 60(3): 420-424.

17. Kostenko VO, Tsebrzhins'kii OI. Production of superoxide anion radical and nitric oxide in renal tissues sutured with different surgical suture material. Fiziol Zh. 2000; 46(5): 56-62. (In Ukrainian).

18. Jiang ZY, Woollard AC, Wolff SP. Hydrogen peroxide production during experimental protein glycation. FEBS Lett. 1990; 268(1): 69-71.
19. Tkachenko MM, Sahach VF, Baziliuk OV, Kotsiuruba AV, Popereka HM, Stepanenko LH, Seniuk OF. Age-related characteristics of contractile vascular reactions and the content of oxygen free radicals and nitric oxide metabolites in BALB/c mice in conditions of alienation zone. Fiziol Zh. 2005; 51(3): 32-41. (In Ukrainian).

20. Coote JL, Work TS. Proteins coded by mitochondrial DNA of mammalian cells. Eur $J$ Biochem. 1971; 23(3): 564-574.

21. Andreyev AY, Kushnareva YE, Starkov AA. Mitochondrial metabolism of reactive oxygen species. Biochemistry (Mosc). 2005; 70(2): 200214.

22. Wei YH, Lee HC. Oxidative stress, mitochondrial DNA mutation, and impairment of antioxidant enzymes in aging. Exp Biol Med (Maywood). 2002; 227(9): 671-682.

23. Wall SB, Oh JY, Diers AR, Landar A. Oxidative modification of proteins: an emerging mechanism of cell signaling. Front Physiol. 2012; 3: 369.

24. Muravleva LYe, Molotov-Luchansky VB, Klyuyev DA. Protein oxidative modification: problems and research prospects. Fundam Res. 2010; 1: 74-78. (Iin Russian).

25. Luo D, Smith SW, Anderson BD. Kinetics and mechanism of the reaction of cysteine and hydrogen peroxide in aqueous solution. $J$ Pharm Sci. 2005; 94(2): 304-316.

26. Cai Z, Yan LJ. Protein oxidative modifications: beneficial roles in disease and health. $J$ Biochem Pharmacol Res. 2013; 1(1): 15-26.

Received 11.01.2016 